\title{
Comparing Self-Efficacy of Government and Private High School Female Students
}

\author{
Chandra Shekhar ${ }^{1 *}$, Rajinder Kumar $^{2}$
}

\section{ABSTRACT}

Self-efficacy is individual's belief that he or she can perform some behavior or task successfully (Baron, 2001). Self-efficacy is hypothesized to affect individuals' task choices, effort, persistence, and achievement (Bandura, 1997; Schunk, 1989). In our present research we had chosen a sample of 100 high school (10th class) female students; 50 from private schools and 50 from government schools within the age group of 14 to 18 years. Our main objective was to see if there is any statistically significant difference in the self-efficacy of the two groups or not. Mean obtained by government sample is 68.54 and by private sample are 70.84 . With the help of t-test we found a significant difference in the mean score of self-efficacy between two samples at 0.05 level of significance as calculated t-ratio is 2.01 and corresponding significance value is 0.47 .

Keywords: Self-Efficacy, Persistence, Achievement, Government And Private Schools.

Self-efficacy is individual's belief that he or she can perform some behavior or task successfully (Baron, 2001). Bandura (1997) defined self-efficacy as "beliefs in one's capabilities to organize and execute the courses of action required to manage prospective situations". These beliefs of personal competence influence the choices individuals make and the courses of action they pursue. Self-efficacy can be defined as our feeling of adequacy, efficiency, and competence in coping with life (Schultz \& Schultz, 2004). Self-efficacy has been found to play a role in success on many tasks (Maurer \& Pierce, 1998). In case of health - people who expect to handle stress effecting or to get better quickly often actually do (Bandura, 1992, as cited in Schwarzer, 1995). Meeting and maintaining our performance standards enhances self-efficacy whereas failure to meet and maintain them reduces it.

\footnotetext{
${ }^{1}$ Sr. Assistant Professor, P.G. Department of Psychology, University of Jammu, Jammu Tawi, India

${ }^{2}$ Senior Research Fellow, P.G. Department of Psychology, University of Jammu, Jammu Tawi, India *Responding Author

(C) 2016, C Shekhar, R Kumar; licensee IJIP. This is an Open Access Research distributed under the terms of the Creative Commons Attribution License (http://creativecommons.org/licenses/by/2.0), which permits unrestricted use, distribution, and reproduction in any Medium, provided the original work is properly cited.
} 


\section{Comparing Self-Efficacy of Government and Private High School Female Students}

Self-efficacy is grounded in the larger theoretical framework of social cognitive theory which postulates that human functioning results from interactions among personal factors (e.g., cognitions, emotions), behaviors, and environmental conditions (Bandura, 1986, 1997). Selfefficacy is hypothesized to affect individuals' task choices, effort, persistence, and achievement (Bandura, 1997; Schunk, 1989).

People high in self-efficacy believe they can deal effectively with events and situations because they expect to succeed in overcoming the obstacles and they persevere at tasks and often perform at a high level. Also these people have greater confidence in their abilities than do persons low in self-efficacy, and they express little self-doubt. In addition to it, they view difficulties as challenges instead of threats and actively seek novel situations. High self-efficacy reduces fear of failure, raises aspirations, and improves problem solving and analytical thinking abilities (Schultz and Schultz, 2013, p. 338).

\section{Sources of Self-Efficacy}

The growth of self-efficacy begins to form in early childhood that does not end during youth, but continues to evolve throughout life as people acquire new skills, experiences, and understanding. According to Bandura (1992) there are four major sources of self-efficacy.

\section{Mastery Experiences}

Performing a task successfully strengthens our sense of self-efficacy. However, failing to adequately deal with a task or challenge can undermine and weaken self-efficacy, Bandura (1992).

\section{Social Modeling}

According to Bandura, "Seeing people similar to oneself succeeding by sustained effort raises observers' beliefs that they too possess the capabilities to master comparable activities to succeed."

\section{Social Persuasion}

Bandura (1992) also asserted that people could be persuaded to believe that they have the skills and capabilities to succeed. Getting verbal encouragement from others helps people overcome self-doubt and instead focus on giving their best effort to the task at hand.

\section{Psychological Responses}

Our own responses such as moods, emotional states, physical reactions, and stress levels can all impact how a person feels about their personal abilities in a particular situation. 


\section{Comparing Self-Efficacy of Government and Private High School Female Students}

\section{Self-efficacy and Students' Outcomes}

Zimmerman, Bandura and Pons (1992) carried out a path analysis to study the casual role of students' self-efficacy beliefs and academic goals in self-motivated academic attainment. It was found that perceived efficacy (self-efficacy) to achieve motivates academic attainment both directly and indirectly by influencing personal goal setting. Self-efficacy and goals in combination contribute to subsequent academic attainments.

Findings on the relationship between self-efficacy, motivation constructs, and academic performances are examined by Pajares (1996). He found the contributions of self-efficacy in selfregulation and motivation in academic settings. A large sample consisted of 10,000 high school students was collected by Trusty and Lampe (1997) in order to see the relationship between parental involvement and self regulatory behaviours. They found that parental involvement had the strongest positive relationship to students' self regulatory behaviours particularly the locus of control especially when adolescents perceived more parental control.

\section{RESEARCH METHODOLOGY}

\section{Sample}

A total of 100 high school ( $10^{\text {th }}$ class) female students; 50 from private schools and 50 from government schools within the age group of 14 to 18 years of Jammu city were chosen for present study.

\section{Objectives}

1. Assessment of the significant difference in self-efficacy of government and private high school female students

\section{Hypothesis}

2. There will be no significant difference in self-efficacy of government and private high school female students

In addition to it we will also compare the mean scores of 8 areas measured by the scale used namely self regulatory skills, self influence, self confidence, social - achievement, self, self evaluation, self esteem, and self-cognition, for these two samples.

\section{Tool Used}

Self-Efficacy Scale (SES - MGBR) by Mathur and Bhatnagar (2012) that consists 22 items in eight area-1) Self Regulatory Skills, 2) Self Influence, 3) Self Confidence, 4) Social Achievement, 5) Self, 6) Self Evaluation, 7) Self Esteem, and 8) Self Cognition. It was standardized on 800 male and female students falling in the age group of 14 year plus. 
Table 1: following table shows the eight factors of self efficacy.

\begin{tabular}{|c|l|l|c|}
\hline S. No. & Factors/Areas & S. No. of items & Total items \\
\hline 1. & Self Regulatory & 15,21 & 02 \\
\hline 2. & Self Influence & $09,14,18$ & 03 \\
\hline 3. & Self Confidence, & $01,04,12$ & 03 \\
\hline 4. & Social Achievement & $03,08,10$ & 03 \\
\hline 5. & Self & $05,17,22$ & 03 \\
\hline 6. & Self Evaluation & $02,07,19$ & 03 \\
\hline 7. & Self Esteem & 13,20 & 02 \\
\hline 8. & Self Cognition & $06,11,16$ & 03 \\
\hline & Total & & $\mathbf{2 2}$ \\
\hline
\end{tabular}

\section{RESULTS AND DISCUSSION}

Our objective was to assess the significant difference in self-efficacy of government and private high school female students and corresponding null hypothesis stated that there will be no significant difference in self-efficacy of government and private high school female students. But in our t-test analysis, given in table- 1 and table-2, we found that there is a significant difference in the mean score of self-efficacy at 0.05 level of significance as calculated t-ratio for two samples is 2.01 and corresponding significance value is 0.04 .

Table-2: following table shows descriptive statistics for government and private female high school students.

\begin{tabular}{|l|l|c|c|c|c|}
\hline S. No. & Samples & $\begin{array}{l}\text { Sample } \\
\text { Size (N) }\end{array}$ & Mean & $\begin{array}{c}\text { Standard } \\
\text { deviation }\end{array}$ & $\begin{array}{c}\text { Standard } \\
\text { error }\end{array}$ \\
\hline 1. & Government & 50 & 68.54 & 6.557 & .927 \\
\hline 2. & Private & 50 & 70.84 & 4.744 & .671 \\
\hline
\end{tabular}

Table-3: following table shows t-test analysis for government and private female high school students.

\begin{tabular}{|l|l|c|c|c|c|}
\hline \multicolumn{1}{|c|}{ S. No. } & Samples & $\begin{array}{l}\text { Sample } \\
\text { Size (N) }\end{array}$ & df & t-ratio & $\begin{array}{c}\text { Sig. } \\
\text { (2-tailed) }\end{array}$ \\
\hline 1. & Government & 50 & 98 & 2.01 & $.04 *$ \\
\hline 2. & Private & 50 & & & \\
\hline
\end{tabular}

There is plenty of research work available on studying gender differences but very few studies have focused on differences in self-efficacy within the gender. Bhagat (2016) in her study gender differences in the self-efficacy of secondary school students found significant gender differences in self-efficacy. The sample of 200 students of $9^{\text {th }}$ class was collected from government and private school students of Jammu district. Class In addition to it we also conducted area wise ttest analysis and found following results given in table- 4 and table- 5 as:

(C) The International Journal of Indian Psychology, ISSN 2348-5396 (e)| ISSN: 2349-3429 (p) | 188 
Table-4: following table shows factor wise descriptive statistics for government and private female high school students.

\begin{tabular}{|c|c|c|c|c|c|}
\hline S. No. & Factors & $\begin{array}{l}\text { Samples } \\
\text { (females) }\end{array}$ & $\begin{array}{l}\text { Sample } \\
\text { Size (N) }\end{array}$ & Mean & $\begin{array}{l}\text { Standard } \\
\text { deviation }\end{array}$ \\
\hline 1. & Self regulatory & $\begin{array}{l}\text { Govt. } \\
\text { Pvt. }\end{array}$ & \multirow{8}{*}{50} & $\begin{array}{l}4.94 \\
5.30 \\
\end{array}$ & $\begin{array}{l}1.910 \\
2.023 \\
\end{array}$ \\
\hline 2. & Self influence & $\begin{array}{l}\text { Govt. } \\
\text { Pvt. }\end{array}$ & & $\begin{array}{l}11.68 \\
12.34\end{array}$ & $\begin{array}{l}2.661 \\
1.880\end{array}$ \\
\hline 3. & Self confidence & $\begin{array}{l}\text { Govt. } \\
\text { Pvt. }\end{array}$ & & $\begin{array}{r}9.98 \\
10.18\end{array}$ & $\begin{array}{l}1.505 \\
1.380\end{array}$ \\
\hline 4. & Social achievement & $\begin{array}{l}\text { Govt. } \\
\text { Pvt. }\end{array}$ & & $\begin{array}{l}9.44 \\
8.90 \\
\end{array}$ & $\begin{array}{l}2.251 \\
2.053\end{array}$ \\
\hline 5. & Self & $\begin{array}{l}\text { Govt. } \\
\text { Pvt. }\end{array}$ & & $\begin{array}{l}8.46 \\
9.58\end{array}$ & $\begin{array}{l}2.243 \\
2.365\end{array}$ \\
\hline 6. & Self evaluation & $\begin{array}{l}\text { Govt. } \\
\text { Pvt. }\end{array}$ & & $\begin{array}{l}9.72 \\
9.94 \\
\end{array}$ & $\begin{array}{l}2.564 \\
1.889\end{array}$ \\
\hline 7. & Self esteem & $\begin{array}{l}\text { Govt. } \\
\text { Pvt. }\end{array}$ & & $\begin{array}{l}3.64 \\
3.66 \\
\end{array}$ & $\begin{array}{l}1.274 \\
1.364 \\
\end{array}$ \\
\hline 8. & Self cognition & $\begin{array}{l}\text { Govt. } \\
\text { Pvt. }\end{array}$ & & $\begin{array}{l}10.68 \\
10.94\end{array}$ & $\begin{array}{l}2.486 \\
2.253\end{array}$ \\
\hline
\end{tabular}

Table-5: following table shows factor wise t-test analysis for government and private female high school students.

\begin{tabular}{|c|c|c|c|c|c|c|}
\hline S. No. & Factors & $\begin{array}{l}\text { Samples } \\
\text { (females) }\end{array}$ & $\begin{array}{l}\text { Sample } \\
\text { Size (N) }\end{array}$ & df & t-ratio & $\begin{array}{c}\text { Sig. } \\
\text { (2-tailed) }\end{array}$ \\
\hline 1. & Self regulatory & $\begin{array}{l}\text { Govt. } \\
\text { Pvt. }\end{array}$ & \multirow{8}{*}{50} & \multirow{8}{*}{98} & 0.915 & .36 \\
\hline 2. & Self influence & $\begin{array}{l}\text { Govt. } \\
\text { Pvt. }\end{array}$ & & & 1.432 & .15 \\
\hline 3. & Self confidence & $\begin{array}{l}\text { Govt. } \\
\text { Pvt. }\end{array}$ & & & 0.692 & .49 \\
\hline 4. & Social achievement & $\begin{array}{l}\text { Govt. } \\
\text { Pvt. }\end{array}$ & & & 1.253 & .21 \\
\hline 5. & Self & $\begin{array}{l}\text { Govt. } \\
\text { Pvt. }\end{array}$ & & & 2.430 & $.01^{* *}$ \\
\hline 6. & Self evaluation & $\begin{array}{l}\text { Govt. } \\
\text { Pvt. }\end{array}$ & & & 0.489 & .62 \\
\hline 7. & Self esteem & $\begin{array}{l}\text { Govt. } \\
\text { Pvt. }\end{array}$ & & & 0.076 & .94 \\
\hline 8. & Self cognition & $\begin{array}{l}\text { Govt. } \\
\text { Pvt. }\end{array}$ & & & 0.548 & .58 \\
\hline
\end{tabular}

(c) The International Journal of Indian Psychology, ISSN 2348-5396 (e)| ISSN: 2349-3429 (p) | 189 


\section{Comparing Self-Efficacy of Government and Private High School Female Students}

From above table it is quite clear that Self is the only factor in which both sample differ significantly at .01 level. Other than self no factor is found to have significant differences in their means of respective samples.

\section{CONCLUSIONS}

There is significant difference in the mean score of self-efficacy between two samples at 0.05 level of significance. But on conducting factor wise t-test analysis for each factor we came to know that two samples differ on only one factor named self.

\section{LIMITATION OF STUDY}

Inclusion of only females in both samples is the main drawback of study. Another thing, both the samples were not enough large.

\section{Acknowledgments}

The author appreciates all those who participated in the study and helped to facilitate the research process.

\section{Conflict of Interests}

The author declared no conflict of interests.

\section{REFERENCES}

Bandura, A. (1986). Social foundations of thought and action: A social cognitive theory. Englewood Cliffs, NJ: Prentice Hall.

Bandura, A. (1993). Perceived self-efficacy in cognitive development and functioning. Educational Psychologist, 28, 117-148.

Bandura, A. (1997). Self-efficacy: The exercise of control. New York: Freeman.

Bandura, A., Barbaranelli, C., Caprara, G. V., \& Pastorelli, C. (1996). Multifaceted impact of self-efficacy beliefs on academic functioning. Child Development, 67, 1206-1222.

Baron, R. (2001). Introduction to psychology. Pearson Prentice Hall, 391-392.

Bhagat, P. (2016). Gender differences in the self-efficacy of secondary school students. International Journal of Current Research, 8(7), pp. 34469-34474.

Mathur, G. P. \& Bhatnagar, R. K. (2012). Manual for Self Efficacy Scale - Hindi. National Psychological Corporation, Agra.

Pajares, F. (1996). Self-efficacy beliefs in achievement settings. Review of Educational Research, 66, 543-578.

Schultz, D. P., \& Schultz, E. S. (2013). Theories of personality. $10^{\text {th }}$ Ed. UK, Cengage Learning, Wadsworth, 15-16.

Schunk, D. H. (1989). Self-efficacy and achievement behaviors. Educational Psychology Review, 1, 173-208.

Schwarzer, R. (1995). Self-efficacy: Thought control of action. Washington, DC: Hemisphere

(C) The International Journal of Indian Psychology, ISSN 2348-5396 (e)| ISSN: 2349-3429 (p) | 190 


\section{Comparing Self-Efficacy of Government and Private High School Female Students}

Trusty, J., \& Lampe, R. E. (1997). Relationship of high-school seniors' perceptions of parental involvement and control to seniors' locus of control. Journal of Counseling \& Development, 75 (5), 375-384.

Zimmerman, B. J., Bandura, A., \& Pons, M. M. (1992). Self-motivation for academic attainment: The role of self-efficacy beliefs and personal goal setting. American Educational Research Journal, 29 (3), 663-674.

How to cite this article: C Shekhar, R Kumar (2016), Comparing Self-Efficacy of Government and Private High School Female Students, International Journal of Indian Psychology, Volume 3, Issue 4, No. 64, ISSN 2348-5396 (e), ISSN: 2349-3429 (p), DIP: 18.01.134/20160304, ISBN: 978-1-365-32519-9 